\title{
EVALUASI APLIKASI SISTEM KEUANGAN DESA (SISKEUDES)
}

\author{
Siti Atikah \\ Fakultas Ekonomi dan Bisnis Universitas Mataram \\ siti.atikah@unram.ac.id \\ Intan Rakhmawati \\ Fakultas Ekonomi dan Bisnis Universitas Mataram \\ intanrakhmawati@unram.ac.id \\ Baiq Rosyida Dwi Astuti \\ Fakultas Ekonomi dan Bisnis Universitas Mataram \\ rosyidabaiq@unram.ac.id \\ D. Tialurra Della Nabilla \\ Fakultas Ekonomi dan Bisnis Universitas Mataram \\ tialurradellanabila@unram.ac.id
}

\section{Article History:}

Received: 5 Feb 2021

Revised: 26 April 2021

Accepted: 26 April 2021
Abstract : This study aims to evaluate Siskeudes V2.0. R.0.1., from the system and its output, which is also analyzed is related to the measurement of efficiency and effectiveness of the use of village funds. Data collection is done by evaluating the application system, and calculating the financial ratio of siskeudes application output, in villages in West Lombok Regency. In terms of system evaluation, as a connection effect between the planning and budgeting stages, implementation and administration, to financial reporting, traceability and connectivity Siskeudes V2.0 R.0.1. better than Siskeudes V1.0.R1.06. The existence of the Activity Package in budgeting and implementing expenditures also makes it easier for the village government to make village financial statements. From the point of view of the village government, the average person has been able to estimate the using of funds and allocation in the activities field. Thus, the ability of the village government in West Lombok Regency in estimating routine expenditures and village capital expenditures (harmony), which has an effect on the efficiency and effectiveness of village funds, has been good. As a suggestion, because there is no automatic measurement of financial efficiency and effectiveness in Siskeudes to measure the financial performance of village governments, researchers advised the Ministry of Finance and the Ministry of Home Affairs to draw up 
regulations for calculating village financial ratios, as well as integrate them in Siskeudes applications.

Abstrak: Penelitian ini bertujuan mengevaluasi Siskeudes V2.0. R.0.1., dari kualitas sistem dan outputnya, yang dianalisis pula keterkaitannya dengan pengukuran efisiensi dan efektivitas penggunaan Dana Desa. Pengumpulan data dilakukan dengan evaluasi sistem aplikasi, dan perhitungan rasio keuangan dari output aplikasi Siskeudes, di desa di Kabupaten Lombok Barat.

Dari segi evaluasi sistem, sebagai efek koneksi antara tahap perencanaan dan penganggaran, pelaksanaan dan penatausahaannya, hingga pelaporan keuangan, ketertelusuran dan konektivitas Siskeudes V2.0 R.0.1. lebih baik daripada Siskeudes V1.0.R1.06. Adanya Paket Kegiatan dalam pembuatan anggaran dan pelaksanaan belanja juga memudahkan pemerintah desa membuat laporan keuangan desa. Dari sudut pemerintah desa, rata-rata sudah mampu memperkirakan penggunaan dana dan mengalokasikan dalam bidang kegiatan. Dengan demikian, kemampuan pemerintah desa di Kabupaten Lombok Barat dalam memperkirakan belanja rutin dan belanja modal desa (keserasian), yang berefek ke efisiensi dan efektivitas Dana Desa, sudah baik.

Sebagai saran, dikarenakan belum ada pengukuran efisiensi dan efektivitas keuangan secara otomatis dalam Siskeudes terhadap pengukuran kinerja keuangan pemerintah desa, peneliti menyarankan Kementerian Keuangan dan Kementerian Dalam Negeri untuk menyusun peraturan untuk penghitungan rasio keuangan desa, serta mengintegrasikannya dalam Siskeudes.

Keywords: System Evaluation, Village Financial Performance, Siskeudes Application

Kata kunci: Evaluasi Sistem, Kinerja Keuangan Desa, Aplikasi Siskeudes

\section{PENDAHULUAN}

Pemerintah desa menyusun laporan dan pertanggungjawaban keuangan yang dibuat melalui aplikasi Sistem Keuangan Desa (selanjutnya disingkat Siskeudes). Siskeudes sudah diluncurkan sejak tahun 2015, namun baru digunakan oleh sebagian besar pemerintah desa sejak tahun 2018. Penggunaan Siskeudes diharapkan dapat meningkatkan tata kelola keuangan desa. Penelitian ini memiliki 2 tujuan. Tujuan yang pertama, penelitian ini bertujuan mengevaluasi aplikasi keuangan desa, dari segi 
output yang dihasilkan dari proses input dalam Siskeudes. Kemudian tujuan yang kedua, penelitian ini akan menganalisis kinerja keuangan desa dari segi efisiensi dan efektivitas, berdasarkan output laporan keuangan desa yang dihasilkan dari Siskeudes. Dengan demikian, tujuan yang kedua terkait pula dengan evaluasi sistem aplikasi, karena rasio dihitung dari output Siskeudes. Analisa efisensi dan efektivitas juga dilakukan karena sepengetahuan peneliti, dengan aplikasi sebelumnya (Siskeudes V1.0.R1.06.), antara anggaran dan realisasi belum ada sistem manajemen basis data (Database Management System - DBMS) yang cukup baik.

Secara lebih lanjut, terkait tujuan pertama, sepengetahuan peneliti, penelitian yang mengevaluasi sistem aplikasi belum banyak dilakukan. Penelitian terdahulu hanya menyangkut kualitas laporan keuangan yang dihasilkan Siskeudes, serta evaluasi penggunaan aplikasi Siskeudes untuk mencapai akuntabilitas dan mencegah kecurangan keuangan desa. Dengan demikian, penelitian terdahulu belum mengkaitkan kualitas laporan keuangan desa sebagai output Siskeudes, dengan proses inputnya dalam aplikasi.

Sementara terkait tujuan penelitian kedua, berdasarkan hasil survey peneliti pada beberapa website pemerintah desa, belum terdeteksi adanya penilaian efisiensi dan efektifitas penggunaan dana pemerintah desa. Dari hasil ini, peneliti melakukan wawancara dengan verifikator di Dinas Pemberdayaan Masyarakat dan Desa (DPMD) Kabupaten Lombok Barat, hasilnya, memang belum ada standar penilaian kinerja dari unsur efisiensi dan efektifitas pengelolaan keuangan desa, yang biasanya dihitung dengan rasio keuangan. Padahal unsur pengukuran kinerja keuangan dari laporan pertanggungjawaban tercantum dalam Permendagri Nomor 20 Tahun 2018 tentang Pengelolaan Keuangan Desa (revisi Permendagri Nomor 113 Tahun 2014 dan Permendagri Nomor 114 Tahun 2014), serta Peraturan Menteri Keuangan Nomor 193/PMK.07/2018. Tidak hanya untuk menentukan alokasi Dana Desa periode berikutnya, predikat kinerja pemerintah daerah juga dianalisa berdasarkan Penyaluran Dana Desa.

Penelitian terdahulu antara lain dilakukan oleh Juardi, dkk (2018). Juardi, dkk (2018) mengungkapkan bahwa desa telah menggunakan Siskeudes dengan baik sehingga mampu menghasilkan laporan keuangan yang akuntabel. Ungkapan ini mendukung hasil penelitian Welingas, dkk (2019), bahwa desa telah memanfaatkan Siskeudes dengan baik dan mampu meningkatkan efisiensi dan efektifitas laporan keuangan desa. Atikah, dkk (2019) juga menungkapkan bahwa desa terbantu dalam penyusunan laporan keuangan menggunakan Siskeudes, namun pemahaman terhadap penggunaan akun aset tetap dan belanja modal dalam konteks jurnal penyesuaian masih belum memadai. Padahal laporan pertanggungjawaban akan digunakan untuk menilai efisiensi dan 
efektifitas anggaran desa (Welingas, dkk, 2019), jumlah dana yang akan disalurkan tahun berikutnya serta program dan kegiatan yang berlanjut periode berikutnya (Atikah, dkk, 2019).

Di sisi lain, dari hasil penelitian terdahulu, masih banyak desa yang belum mampu menyerap anggaran. Hasil penelitian Siregar dan Syam (2017) mengemukakan bahwa dari tingkat efektivitas penggunaan Alokasi Dana Desa (selanjutnya disingkat ADD) desa-desa di Kabupaten Deli Serdang masih beragam, karena ada desa yang mampu menyerap anggaran atas ADD sangat efektif (100\%), namun ada desa yang dinilai belum mampu melakukan penyerapan anggaran secara maksimal. Sementara itu, pada analisis efisiensi, cenderung terlihat bahwa masih kurang efisien secara stabil antar periode, baik itu penyerapan ADD maupun Dana Desa.

Penelitian lain juga dilakukan oleh Ramadhani, et al (2019), tentang analisis rasio keuangan untuk menilai kinerja Anggaran Pendapatan dan Belanja Desa (selanjutnya disingkat APBDesa) pada Desa Bulak, Kecamatan Bendo, Kabupaten Magetan. Hasil analisis rasio keuangan Desa Bulak tahun 2015-2017 menunjukkan dari aspek kemandirian masih sangat rendah, dari aspek keserasian belanja rutin dan belanja modal juga masih kurang baik selama 3 tahun. Hal ini terkait dengan perbaikan untuk pengelolaan PADesa seperti dari BUMDes, dan juga pengalokasian dana yang tepat. Ramadhani, et al (2019) juga menyarankan hal ini agar tidak terjadi pemborosan anggaran.

\section{TELAAH LITERATUR DAN PENGEMBANGAN HIPOTESIS}

Model yang digunakan untuk mengevaluasi Siskeudes pada penelitian ini yaitu DeLone and McLean Information System Success Model. Model kesuksesan Siskeudes V2.0. R.0.1. ditinjau dari kualitas output sistem.

Aplikasi Siskeudes V2.0 R.0.1. sendiri mengalami beberapa penyesuaian dari versi sebelumnya terkait dengan dirilisnya peraturan terbaru Permendagri 20 Tahun 2018 yang bertujuan untuk memenuhi kebutuhan desa, dengan adanya Paket Kegiatan. Penyesuaian juga dilakukan dengan penambahan 1 parameter, yaitu Parameter Output Kegiatan Dana Desa sehingga pada versi terbaru ini terdapat 10 (sepuluh) parameter.

Jika ditinjau dari kualitas output sistem, peneliti bergerak dari proses pengelolaan keuangan desa, sebagaimana diregulasikan dari Peraturan Pemerintah No. 43 Tahun 2014 jo Peraturan Pemerintah No. 47 Tahun 2015, Peraturan Pemerintah No. 60 Tahun 2014 jo Peraturan Pemerintah No. 22 Tahun 2015 jo Peraturan Pemerintah No. 8 Tahun 2016, Peraturan Menteri Dalam Negeri No. 113 dan No. 114 Tahun 2014 jo Permendagri Nomor 20 Tahun 2018, Peraturan Menteri Keuangan No. 93 Tahun 2015 jo Peraturan Menteri Keuangan No. 247 Tahun 2015 jo 
Peraturan Menteri Keuangan No. 49 Tahun 2016, Peraturan Menteri Keuangan No. 225 Tahun 2017, dan Peraturan Kementerian Desa, Transmigrasi, dan PDT Nomor 16 Tahun 2018 Tentang Prioritas Penggunaan Dana Desa Tahun 2019. Dari semua peraturan tersebut, kualitas output dari aplikasi Siskeudes kemudian dianalisis berdasarkan ketertelusuran dan pencocokan laporan keuangan (termasuk laporan penggunaan Dana Desa) dari aplikasi Siskeudes. Dengan demikian, peneliti meninjau konektivitas antar fase pengelolaan keuangan desa sesuai regulasi.

Analisis kemudian juga dihubungkan dengan rasio keuangan. Untuk penghitungan rasio untuk keuangan desa, yang dikonversi dari rasio keuangan pemerintah daerah berdasarkan Keputusan Menteri Dalam Negeri Nomor. 690.900.327 Tahun 1996 tentang Pedoman dan Penilaian Kinerja Keuangan. Penilaian tersebut terdiri dari:

a. Rasio Kemandirian, menggambarkan kemandirian keuangan desa (besar atau kecilnya Pendapatan Asli Desa(PADes), yang kemudian dibandingkan dengan pendapatan desa dari sumber lainnya. Rumusnya untuk desa menjadi:

$$
\text { Rasio Kemandirian }=\frac{\text { Pendapatan Asli Desa }}{\text { Bantuan Pusat }+ \text { Pinjaman }} X 100 \%
$$

Dalam hal ini, "Bantuan Pusat" pada rumus di atas dikonversi menjadi bantuan dana eksternal dari pemerintah kabupaten (Alokasi Dana Desa) dan pemerintah pusat (Dana Desa), dan bantuan keuangan. Kriterianya, jika dari perhitungan rasio kemandirian kurang dari 50\%, maka desa dianggap belum mandiri, karena masih mengandalkan sumber dari pemerintah pusat.

b. Rasio Keserasian, diartikan sebagai prioritas alokasi dana belanja rutin dan belanja modal dari keseluruhan total anggaran belanja desa. Rasio ini dipecah menjadi 2 sisi, yaitu dari sisi belanja rutin dan belanja modal.

$$
\begin{aligned}
\text { Rasio Belanja Rutin } & =\frac{\text { Belanja Rutin }}{\text { Total APBDes }} \\
\text { Rasio Belanja Modal } & =\frac{\text { Belanja Modal }}{\text { Total APBDes }}
\end{aligned}
$$


Kriteria:

\begin{tabular}{|c|c|}
\hline $\begin{array}{c}\text { Nilai Perbandingan } \\
\text { Belanja Rutin: Belanja } \\
\text { Modal (\%) }\end{array}$ & $\begin{array}{c}\text { Kriteria } \\
\text { Keserasian }\end{array}$ \\
\hline $\begin{array}{c}40: 40 \text { atau } 40: 50 \text { atau } 50: \\
40\end{array}$ & Baik \\
\hline $70: 30$ atau $80: 20$ & Kurang Baik \\
\hline $90: 10$ & Tidak Baik \\
\hline
\end{tabular}

c. Rasio Pertumbuhan, diartikan sebagai pertumbuhan kemampuan desa dari perkembangan kemampuan (pertumbuhan) pendapatan dan belanjanya, untuk memenuhi kebutuhan belanja.

Keterangan:

$\mathrm{t} \quad$ : tahun berjalan

t-1 : tahun sebelumnya

Kriteria:

\begin{tabular}{|c|c|}
\hline $\begin{array}{c}\text { Nilai Rasio } \\
\text { Pertumbuhan (\%) }\end{array}$ & $\begin{array}{c}\text { Tingkat } \\
\text { Pertumbuhan }\end{array}$ \\
\hline$>100$ & Sangat Tinggi \\
\hline $90-100$ & Tinggi \\
\hline $70-90$ & Cukup \\
\hline $50-70$ & Rendah \\
\hline$<50$ & Sangat Rendah \\
\hline
\end{tabular}

d. Rasio efisiensi, menggambarkan perbandingan antara keluaran atau output (belanja) yang dihasilkan dengan input (pendapatan) yang digunakan.

$$
\text { Rasio Efisiensi }=\frac{\text { Total Realisasi Belanja Desa }}{\text { Total Realisasi Pendapatan Desa }} \times 100 \%
$$


Kriteria:

\begin{tabular}{|c|c|}
\hline $\begin{array}{c}\text { Nilai Rasio Efisiensi } \\
(\mathbf{\%})\end{array}$ & Tingkat Efisiensi \\
\hline$>100$ & Sangat Efisien \\
\hline $90-100$ & Efisien \\
\hline $80-90$ & Cukup Efisien \\
\hline $60-80$ & Kurang Efisien \\
\hline$<60$ & Tidak Efisien \\
\hline
\end{tabular}

e. Rasio efektivitas, terdiri dari efektivitas pendapatan dan efektivitas belanja. Dari segi pendapatan, efektivitas berarti perbandingan realisasi Pendapatan Asli Desa (PADes) dengan target yang telah ditetapkan dalam anggaran. Rumusnya menjadi:

Rasio Efektivitas Pendapatan $=\frac{\text { Realisasi Total Pendapatan }}{\text { Target }(\text { Anggaran }) \text { Pendapatan }} \times 100 \%$

Sementara efektivitas belanja menggambarkan keterlaksanaan program sesuai dengan anggaran desa, hal ini terlihat dari pencapaian target sesuai angggaran belanja. Rumusnya menjadi:

Rasio Efektivitas Belanja $=\frac{\text { Realisasi Total Anggaran Belanja }}{\text { Anggaran Belanja }} \times 100 \%$

Kriteria tingkat efektifitas anggaran pendapatan dan belanja desa yaitu:

\begin{tabular}{|c|c|}
\hline $\begin{array}{c}\text { Nilai Rasio } \\
\text { Efektivitas (\%) }\end{array}$ & $\begin{array}{c}\text { Tingkat } \\
\text { Efektivitas }\end{array}$ \\
\hline$>100$ & Sangat Efektif \\
\hline $90-100$ & Efektif \\
\hline $80-90$ & Cukup Efektif \\
\hline $60-80$ & Kurang Efektif \\
\hline$<60$ & Tidak Efektif \\
\hline
\end{tabular}




\section{METODE PENELITIAN}

Berdasarkan jenisnya, penelitian ini merupakan penelitian evaluasi yang dipadukan dengan penelitian pengembangan. Penelitian evaluasi karena bertujuan untuk mengevaluasi aplikasi Keuangan Desa (Siskeudes), dari segi dari kualitas sistem. Sementara penelitian ini juga merupakan penelitian pengembangan, karena mencoba menghitung dan mengkonversi pengukuran kinerja keuangan untuk pemerintah desa dari laporan keuangan desa, berdasarkan Keputusan Menteri Dalam Negeri Nomor. 690.900.327 Tahun 1996.

Subyek penelitian ini adalah sistem aplikasi Keuangan Desa dan outputnya. Evaluasi dan pengembangan akan dianalisis dan dihitung dari data desa di Kabupaten Lombok Barat, ditambah triangulasi dengan verifikator Dana Desa Pada Dinas Pemberdayaan Masyarakat dan Desa (DPMD) Kabupaten Lombok Barat. Sementara objek penelitian terkait tujuan penelitian yang pertama yaitu aplikasi Sistem Keuangan Desa (Siskeudes) dan outputnya, yang akan dievaluasi kualitas sistemnya. Evaluasi dilakukan atas hal-hal berikut:

1. Konektivitas antar fase pengelolaan keuangan desa sesuai regulasi.

2. Desain tata letak interface dan formulir hingga catatan dalam Siskeudes.

Analisis kemudian akan menghubungkan rasio keuangan ini dengan evaluasi atas sistem aplikasi keuangan desa. Untuk penghitungan rasio untuk keuangan desa, yang dikonversi dari rasio keuangan pemerintah daerah, akan dihitung dari Ikhtisar Anggaran dan Realisasi Pendapatan Desa 2019, sebagaimana telah dijelaskan di atas. Kedua analisa dari evaluasi sistem aplikasi maupun kinerja keuangan ini yang kemudian akan dikaitkan oleh peneliti.

\section{HASIL PENELITIAN DAN PEMBAHASAN}

Sejak 2015, pemerintah desa sudah menggunakan aplikasi Sistem Keuangan Desa (Siskeudes) untuk menghasilkan laporan keuangan dan laporan pertanggungjawaban. Siskeudes terus mengalami perkembangan, sesuai peraturan keuangan desa, dan perbaikan. Standar awal sistem keuangan desa sudah berubah pada 2018, dengan adanya Permendagri Nomor 20 Tahun 2018 tentang Pengelolaan Keuangan Desa, sebagai revisi Permendagri Nomor 113 Tahun 2014 dan Permendagri Nomor 114 Tahun 2014.

Jika pada Permendagri Nomor 113 Tahun 2014, Kepala Desa menjadi pelaksana pengelola keuangan desa, yang dibantu PTPKD, dalam Permendagri Nomor 20 Tahun 2018 Kepala Desa memberikan sebagian kewenangannya pada Pejabat Pengelola Keuangan Desa (PPKD). Menurut peneliti, hal ini diubah demikian, karena kompetensi aparat PPKD yang lebih bervariasi, mulai perencanaan hingga keuangan, daripada dipegang sendiri oleh Kepala Desa. Hal ini juga berfungsi untuk memperkecil potensi 
kecurangan di desa. Selain itu, perubahan krusial juga terjadi pada bagian keuangan desa. Jika dulu dinamakan bendahara (karena hanya menyangkut teknis tata usaha penerimaan dan pengeluaran desa), saat ini namanya sudah dialihkan menjadi Kaur Keuangan, karena memiliki kewajiban menyusun RAK Desa juga, hingga penatausahaan dan pelaporannya.

Dari segi sistem, karena menggunakan basis kas, buku kas umum ditutup setiap akhir bulan. Pada Siskeudes V2.0 R.0.1, sudah ada koneksi antara APBDesa dan APBDes Perubahan, dengan adanya kolom pembetulan jumlah bertambah/berkurang pada formulir RAB Perubahan, dan penambahan baris nama kegiatan dalam laporan APBDesa per Kegiatan. Menurut website updesa.com, adanya menu perubahan pada APBDes Siskeudes versi 2 ini juga terkait dengan Permendagri No.20 Tahun 2018 dimana terdapat:

- Penambahan dan/atau pengurangan pendapatan desa tahun berjalan.

- Adanya sisa belanja dan sisa pembiayaan tahun berjalan, yang akan digunakan pada tahun ini.

- Jika ada sebab yang mengharuskan dilakukan pergeseran antar bidang, sub bidang, kegiatan, dan jenis belanja.

Dari segi anggaran belanja dengan pelaksanaan, dalam Siskeudes versi 2, anggaran belanja desa juga sudah dijadikan Paket Kegiatan, yang terkait antara perencanaan, anggaran, dan pelaksanaannya. Kodefikasi bidang dan sub bidang dalam anggaran ini harus mengikuti Permendagri Nomor 20 Tahun 2018, tidak boleh diubah. Yang diperkenankan untuk diubah adalah kodefikasi kegiatan. Standar harga untuk Paket Kegiatan (termasuk dalam penyusunan Rencana Kerja Kegiatan Desa dan Rencana Anggaran Biaya) ditetapkan dari kabupaten setempat, namun tidak dikunci karena tergantung kondisi geografis desa. Oleh karena itu, angka ini juga terkoneksi dengan angka Indikasi Kebutuhan Dana Desa, yang terkoneksi juga dengan pengukuran kinerja pelaksanaan Dana Desa.

Pelaporan kegiatan yang telah dianggarkan dan dilaksanakan ini dilakukan melalui Laporan Realisasi Anggaran Desa per Kegiatan. Laporan ini terhubung juga dengan Laporan Realisasi APBDes - Laporan Realisasi APBDes per Sumber Dana, dan Laporan Realisasi Penggunaan Dana Desa.

Sementara dalam penatausahaan, laporan ini juga terkoneksi dengan Laporan Perkembangan Pelaksanaan Kegiatan dan Anggaran, Laporan Kegiatan yang belum selesai dan/atau tidak terlaksana, dan sisa anggaran. Dengan demikian, dari segi ketertelusuran dan konektivitas anggaran, realisasi, dan laporan. Siskeudes V2.0 R.0.1. lebih baik daripada Siskeudes V1.0.R1.06., karena ada konektivitas anggaran dan realisasi Paket Kegiatan.

Hal ini juga diakui lebih baik, berdasarkan wawancara dengan beberapa Kaur Keuangan desa di Kabupaten Lombok Barat serta 
verifikator di Dinas Pemberdayaan Masyarakat dan Desa (DPMD). Sebagai akhirnya, kesemua laporan yang terkait dengan Dana Desa juga terkoneksi dengan Laporan Penyerapan Dana Desa PMK 225.

Dari segi evaluasi output sistem, waktu respon sistem juga cukup baik, karena sudah ada pembaruan isi data secara otomatis melalui OMSPAN, antara aparat PPKD, administrator sekaligus verifikator dinas, dan Direktorat Jenderal Perbendaharaan (DJPb) Kementerian Keuangan untuk monitoring evaluasi. Di Kabupaten Lombok Barat, sistem ini sudah terintegrasi, karena mayoritas desa sudah dapat merencanakan, menganggarkan, dan melaksanakan dengan cukup tepat, termasuk untuk belanja desa yang telah dianggarkan, dengan ketepatan waktu yang cukup baik. Dari penjelasan di atas, dari segi evaluasi kualitas sistem, Siskeudes versi 2 sudah lebih baik dibanding Siskeudes versi 1. Selanjutnya, analisis juga dilakukan dengan rasio keuangan, yang sumber datanya ditarik dari laporan dari sistem aplikasi keuangan desa, Siskeudes. Berikut perhitungannya:

Tabel 1. Rasio Keuangan Keseluruhan Desa di Kabupaten Lombok Barat

\begin{tabular}{|l|c|c|}
\hline \multicolumn{1}{|c|}{ Jenis Rasio } & Nilai Rasio (\%) & Kesimpulan \\
\hline Rasio Kemandirian & 44,98 & Rendah \\
\hline $\begin{array}{l}\text { Rasio Keserasian: } \\
\text { > Belanja Rutin } \\
\text { > Belanja Modal }\end{array}$ & 48,60 & \\
\hline Rasio Pertumbuhan & 44,90 & Baik/Serasi \\
\hline Rasio Efisiensi & 97,80 & Tinggi \\
\hline $\begin{array}{l}\text { Rasio Efektivitas: } \\
\text { > Efektivitas Pendapatan } \\
\text { > Efektivitas Belanja }\end{array}$ & 94,25 & Efisien \\
\hline
\end{tabular}

Sumber: Data Sekunder diolah

Dilihat dari rasio kemandirian dan rasio keserasian, tingkat kemandirian desa di Kabupaten Lombok Barat masih rendah. Hal ini dikarenakan desa-desa di Kabupaten Lombok Barat masih tergantung dari Dana Desa, Alokasi Dana Desa, dan Bantuan Keuangan. Persentase PADes $44,98 \%$ (di bawah 50\%), sehingga pemerintah desa di Kabupaten Lombok Barat perlu menggali kembali sumber potensi-potensi untuk meningkatkan Pendapatan Asli Desa.

Sementara dari segi keserasian antara belanja rutin dengan belanja modal, rata-rata pemerintah desa di Kabupaten Lombok Barat masih menggunakan banyak pendapatan desanya untuk penyelenggaraan 
pemerintah (belanja rutin) sebesar $48,60 \%$. Walaupun demikian, persentase untuk belanja modal, termasuk untuk pembangunan sarana dan pemberdayaan masyarakat desa cukup baik, yaitu 44,90\%, sedangkan sisanya digunakan untuk belanja tak terduga.

Dari rasio pertumbuhan yang dilihat dari total pendapatan desa (Pendapatan Asli Desa, Dana Desa, Alokasi Dana Desa, Bagi Hasil, dan Bantuan Keuangan), pertumbuhan desa di Kabupaten Lombok Barat sudah baik, karena bisa memenuhi kebutuhan belanja. Namun jika digali dari sumber pendapatan, terkait rasio kemandirian, karena mayoritas persentase masih dari Dana Desa dan Alokasi Dana Desa, desa di Kabupaten Lombok Barat belum cukup mandiri, karena Pendapatan Asli Desa masih belum optimal digali potensinya. Oleh karena itu, disarankan bagi pemerintah desa untuk menyesuaikan perencanaan Dana Desa dengan kebutuhan dan atau kegiatan pengembangan BUMDes.

Jika dikaitkan dengan BUMDes dan Desa Wisata, di Kabupaten Lombok Barat, walaupun sudah cukup banyak potensi objek lokasi yang dapat dijadikan wisata, namun banyak di antaranya yang pengelolaannya perlu lebih diintensifkan kerjasama dengan BUMDes, dan juga tempat usaha/UMKM yang berbasis handycraft maupun ragam makanan khas.

Selain dengan BUMDes, desa juga perlu mengoptimalkan anggarannya untuk kerjasama antar desa dan kawasan perdesaan. Berdasarkan Peraturan Menteri Dalam Negeri (Permendagri) Nomor 38 Tahun 2007 jo. Permendagri Nomor 96 Tahun 2017 Pasal 3 Ayat 1, kerjasama antar desa yang dimaksud dalam hal ini bisa mencakup antar desa dalam kecamatan yang sama maupun kerjasama antar desa dalam kecamatan yang berbeda (Supra Desa).

Lebih lanjut, jika disejajarkan antara rasio pertumbuhan dan rasio efektivitas, rasio pertumbuhan dan rasio efektivitas desa di Pemerintah Kabupaten Lombok Barat sudah sejalan. Dari rasio pertumbuhan, desa di Kabupaten Lombok Barat termasuk tinggi pertumbuhannya, karena kenaikan dari pendapatan tahun sebelumnya sangat signifikan, sehingga bisa menutup belanja. Sementara dari efektivitas, desa di Kabupaten Lombok Barat juga sangat efektif, dalam pencapaian target pendapatan, dan efektif pula dalam penggunaan anggaran belanja, tanpa adanya pemborosan anggaran. Dengan demikian, penggunaan Paket Kegiatan bagi desa di Kabupaten Lombok Barat, seperti dijelaskan di atas, tidak menjadi masalah. Bahkan penggunaan Siskeudes versi 2 ini mempermudah input, karena pemecahan penganggaran hingga di sub bidang kegiatan belanja desa. Pemerintah desa di Kabupaten Lombok Barat rata-rata sudah dapat menyesuaikan sistem keuangan di desanya, serta dapat cukup memperkirakan penggunaan dana, serta pengalokasiannya dalam bidang kegiatan.

Namun jika sistem aplikasi keuangan desa dikaitkan dengan rasio, walaupun ada integrasi sistem demikian, jika desa dapat mengelola 
anggarannya dengan efektif ataupun sangat efektif, belum ada "penandanya" juga dalam aplikasi Siskeudes, baik dalam pendapatan, belanja, maupun pembiayaan, sehingga pemerintah pusat, dalam hal ini kementerian yang terkait dengan keuangan desa yang telah disebutkan di atas, harus menganalisis rasio efisiensi maupun efektivitas pengelolaan keuangan, dengan metode setengah manual. Sebagai kesimpulan, secara keseluruhan tingkat efisiensi dan efektivitas dalam pengelolaan keuangan desa setelah pemakaian aplikasi Siskeudes versi 2 (Siskeudes V2.0 R.0.1.) menjadi lebih optimal, walaupun berdasarkan dokumentasi peneliti yang telah dijelaskan sebelumnya, penghitungan rasio keuangan sebagai bagian dari standar laporan keuangan desa juga belum terintegrasi, karena belum ada dalam peraturan dari kementerian.

Oleh karena itu, jika ditinjau dari segi peraturan, sayangnya hal ini menjadikan kurangnya sinkronisasi antara pengukuran dalam aplikasi Siskeudes dengan Peraturan Menteri Keuangan Nomor 193/PMK.07/2018 Pasal 40, dimana pemantauan capaian output Dana Desa dilakukan untuk mengetahui capaian perkembangan kegiatan yang dibiayai Dana Desa (yang dirumuskan melalui Paket Kegiatan dalam Siskeudes), dan Pasal 43 ayat 2 yang menyatakan bahwa jika capaian output Dana Desa kurang dari 50\% (lima puluh persen), Kepala KPPN selaku KPA Penyaluran Dana Desa dapat meminta konfirmasi dan klarifikasi kepada bupati. Masih pada peraturan yang sama, hal ini terkait pula dengan Pasal 21, dimana hal ini mempengaruhi transfer Dana Desa tahap berikutnya. Kembali dengan keterkaitannya dengan sistem, masih belum ada sinkronisasi "warning/pemberi peringatan", jika capaian kurang dari persentase yang dianggarkan.

Penghitungan rasio keuangan sebagai bagian dari standar laporan keuangan desa juga belum diintegrasikan dalam peraturan dari kementerian terlebih aplikasi, sehingga yang baru dilihat sebagai standar keberhasilan kinerja pemerintah desa baru pada ketepatan pelaporan dan pertanggungjawaban, serta penggunaan/alokasi pendapatannya untuk dibelanjakan.

\section{SIMPULAN}

Dari segi evaluasi sistem aplikasi, sebagai efek koneksi antara tahap perencanaan dan penganggaran, bahkan hingga pelaporan, ketertelusuran dan konektivitas anggaran, realisasi, dan laporan, Siskeudes V2.0 R.0.1. lebih baik daripada Siskeudes V1.0.R1.06. Adanya Paket Kegiatan dalam pembuatan anggaran dan pelaksanaan belanja juga memudahkan aparat PPKD, sehingga di Kabupaten Lombok Barat, hal ini berpengaruh positif terhadap ketepatan waktu pemerintah desa dalam membuat laporan keuangan desa. Pemerintah desa di Kabupaten Lombok Barat sudah mampu memperkirakan penggunaan dana, serta 
pengalokasiannya dalam bidang kegiatan, sesuai Permendagri Nomor 20 Tahun 2018.

Namun berdasarkan perhitungan rasio keuangan, walaupun rasio efisiensi dan efektivitas pemerintah desa di Kabupaten Lombok Barat juga sudah tinggi, karena kemampuannya memperkirakan penggunaan Dana Desa, namun pemerintah desa di Kabupaten Lombok Barat masih perlu menggali dan mengoptimalkan kembali sumber untuk meningkatkan Pendapatan Asli Desa, agar dapat lebih mandiri.

Dari keterkaitan antara pengukuran kinerja keuangan desa dengan evaluasi sistem, walaupun pemerintah desa berhasil mencapai tingkat efisiensi dan efektivitas tertentu,kementerian masih perlu menganalisisnya secara manual, walaupun sudah ada OM-SPAN dalam Siskeudes. Penghitungan rasio keuangan sebagai bagian dari standar laporan keuangan desa juga belum diintegrasikan dalam peraturan dari kementerian terlebih aplikasi, sehingga yang baru dilihat sebagai standar keberhasilan kinerja pemerintah desa baru pada ketepatan pelaporan dan pertanggungjawaban, serta penggunaan/alokasi pendapatannya untuk dibelanjakan.

\section{DAFTAR PUSTAKA}

Atikah, Siti; Sapto Hendri BS; dan Intan Rakhmawati. Juni 2019. Implementasi Pendapatan, Belanja dan Pelaporan Keuangan Desa. Jurnal Riset Akuntansi Aksioma, Volume 18, Nomor 1. Universitas Mataram: Fakultas Ekonomi dan Bisnis.

Departemen Dalam Negeri Republik Indonesia. 2007. Keputusan Menteri Dalam Negeri Nomor 690.900.327 Tahun 1996 Tentang Pedoman Penilaian dan Kinerja Keuangan. Jakarta: Kementerian Dalam Negeri Republik Indonesia.

Kementerian Dalam Negeri Republik Indonesia. 2007. Peraturan Menteri Dalam Negeri Nomor 38 Tahun 2007 tentang Kerjasama Desa. Jakarta: Kementerian Dalam Negeri Republik Indonesia. Tahun 2014 tentang Dana Desa yang Bersumber dari Anggaran Pendapatan dan Belanja Negara. Jakarta: Kementerian Dalam Negeri Republik Indonesia.

113 Tahun 2 Kementerian Dalam Negeri Republik Indonesia.

114 Tahun 2014 tentang Pedoman Pembangunan Desa. Jakarta: Kementerian Dalam Negeri Republik Indonesia.

Tahun 2016 tentang Perubahan Kedua Atas Peraturan Menteri

Dalam Negeri Nomor 60 Tahun 204 tentang Dana Desa yang 
Bersumber dari Anggaran Pendapatan dan Belanja Negara. Jakarta: Kementerian Dalam Negeri Republik Indonesia. . 2017. Peraturan Menteri Dalam Negeri Nomor 96 Tahun 2017 tentang Tata Cara Kerjasama Desa di Bidang Pemerintahan Desa. Jakarta: Kementerian Dalam Negeri Republik Indonesia. Tahun 2018 tentang Pengelolaan Keuangan Desa. Jakarta: Kementerian Dalam Negeri Republik Indonesia.

Kementerian Keuangan Republik Indonesia. 2018. Peraturan Menteri Dalam Negeri Nomor 193/PMK.07/2018 tentang Pengelolaan Dana Desa. Jakarta: Kementerian Keuangan Republik Indonesia.

Juardi, Mohammad Sapril Sardi; Mustakim Muchlis; dan Rezki Amalia Putri. 2018. Evaluasi Penggunaan Aplikasi Siskeudes dalam Upaya Peningkatan Kualitas Akuntabilitas Keuangan Desa (Studi pada Desa Jenetallasa Kecamatan Pallangga Kabupaten Gowa). Jurnal IImiah Akuntansi Peradaban, Volume 4, Nomor 1; Makassar: Universitas Islam Negeri Alauddin; https://doi.org/10.24252/jiap.v4i1.5159.

Ramadhani, Dizzy Asrinda Siswi; Nur Hisamuddin, dan Moch. Shulthoni. 2019. Analisis Rasio Keuangan untuk Menilai Kinerja APBDesa (Studi Kasus Desa Bulak Kecamatan Bendo Kabupaten Magetan). Jurnal Akuntansi Universitas Jember, Volume 17 Nomor 1. Jember: Universitas Jember.

Siregar, Fachrul A. dan Fazli Syam BZ. 2017. Analisis Efektifitas dan Efisiensi Pengelolaan Keuangan Desa (Studi pada Desa di Kabupaten Deli Serdang). Jurnal IImiah Mahasiswa Ekonomi Akuntansi (JIMEKA), Volume 2, Nomor 4, Halaman 93-106. Aceh: Universitas Syiah Kuala.

Widodo MS, Joko. 2018. Analisis Kebijakan Publik Konsep dan Aplikasi Analisis Proses Kebijakan Publik. MS. Malang: Media Nusa Creative. 